[Agr. Biol. Chem., Vol. 27, No. 3, p. 162 164, 1963]

\title{
The Formation of Higher Alcohols in the Fermentation of Amino Acids by Yeast
}

\author{
The Formation of Active Amyl Alcohol from $\alpha$-Keto- $n$-butyric Acid by \\ Cell-Free Extract of Yeast
}

By Kiyoshi Yoshizawa

The Research Institute of Brewing, Tokyo

Received September 3, 1962

\begin{abstract}
Examination was made on the formation of active amyl alcohol by yeast cell-free extract from $a$-keto- $n$-butyric acid, which is considered to be the first intermediate of $a$-amino- $n$ butyric acid or threonine. About $40 \%$ of assimilated $a$-keto- $n$-butyric acid was converted to active amyl alcohol at pH 5.2. TPN and DPN were effective, but magnesium was not effective upon the formation of active amyl alcohol.
\end{abstract}

\section{INTRODUCTION}

We have confirmed that some amino acids were converted by yeast to the alcohols with one more carbon atoms than the original amino acids, i.e., isobutyl alcohol from alanine and active amyl alcohol from a-amino- $n$ butyric acid or threonine ${ }^{1}$, and in the same time $n$-propyl alcohol was also formed from the latter two amino acids according to $\mathrm{F}$. Ehrlich's scheme. The activity of the formation of these alcohols varied largely according to the yeast strains and incubation conditions, e.g., aeration and $\mathrm{pH}$ of the medium. In any case an appreciable amount of isoleucine was detected in the incubated solution containing $a$-amino- $n$-butyric acid or threonine, and valine was found in the incubated solution containing alanine ${ }^{2)}$. From these results it was presumed that these alcohols were formed via the synthetic pathway

1) M. Yamada, This Journal, 8, 95 (1932); 11, 24 (1935); M. Yamada and K. Yoshizawa, ibid., 24, 266 (1960); K. Yoshizawa et al., ibid., 25, 326 (1961).

2) Yamada ct al., J. Fer. Ass., Japan, 20, 134 (1962). of isoleucine and valine from $a$-amino- $n$ butyric acid or threonine and alanine. The postulated scheme of the formation of active amyl and $n$-propyl alcohol from the amino acids mentioned above was proposed ${ }^{3)}$, which had been supported by the work of Ingraham and Guymon ${ }^{4)}$ on the formation of higher alcohols by mutant strains of yeast.

In this report, the result is described on the examination of the formation of active amyl alcohol from $\alpha$-keto- $n$-butyric acid, which is considered the first intermediate of $a$-amino$n$-butyric acid or threonine in this pathway.

\section{EXPERIMENTAL}

Preparation of Yeast Cell-Free Extract. Fresh cells of Saccharomyces cerevisiae, Kyokai No. 7 mixed with fine glass beads were suspended in $0.02 \mathrm{~m}$ phosphate buffer solution at $\mathrm{pH} 7.2$ and disrupted with the nossal disintegrater for 2 minutes. After centrifugation of the disrupted materials at 15,000 r.p.m., the supernatant fluid was dialyzed against $0.02 \mathrm{~m}$ phosphate buffer solution of $\mathrm{pH} 7.2$ at $0^{\circ} \mathrm{C}$ for 24 hours.

3) K. Yoshizawa and M. Yamada, This Journal, 26, 494 (1962).

4) J.L. Ingraham and J.F. Guymon, Archives Biochem. Biophys., 88, 157 (1960). 
One $\mathrm{ml}$ of this dialyzed cell-free extract contained approximately $10 \mathrm{mg}$ of protein (by ultraviolet absorption) and represented $0.3 \mathrm{~g}$ of fresh yeast.

Incubation Procedure. Two $\mathrm{ml}$ of the yeast cellfree extract was added in $8 \mathrm{ml}$ of $a$-keto- $n$-butyric acid solution the composition of which is shown in Table I. The reaction mixture was incubated with constant shaking at $30^{\circ} \mathrm{C}$ for 5 hours. Then $9 \mathrm{ml}$ of the mixture was distilled to give $0.9 \mathrm{ml}$ of distillate after addition of $0.2 \mathrm{ml}$ of ethyl alcohol. The distillate was used for determination of active amyl alcohol. Keto acids in the residual mixture were determined and amino acids were identified.

TABle I. The Composition of the Incubated SOLUTION

$\begin{array}{lc}\alpha \text {-Keto- } n \text {-butyric acid } & 16 \mathrm{mg} \\ \text { (Glucose) } & (10 \mathrm{mg}) \\ \text { M/5 Phosphate buffer solution }(\mathrm{pH} 5.2) & 2.0 \mathrm{ml} \\ \text { TPN } & 0.1 \mathrm{mg} \\ \text { DPN } & 0.5 \mathrm{mg} \\ \text { Magnesium sulfate } & 5.0 \mathrm{mg} \\ \text { Cell-free extract } & 2.0 \mathrm{ml} \\ \text { Total volume } & 10.0 \mathrm{ml}\end{array}$

Analysis. Since the higher alcohols formed consisted mainly of active amyl alcohol and traces of $n$ propyl and isobutyl alcohol from the results of gas chromatography of the distillate of the reaction mixture, the method of fractional determination of active amyl and isobutyl alcohol was almost the same as the method of fractional determination of isobutyl and amyl alcohols described in the previous paper ${ }^{5}$. The standard solution used consisted of active amyl and isobutyl alcohol. The method of determination of keto acids was the same as described in the previous paper $^{3)}$ except that $0.5 \mathrm{ml}$ of the mixture was used for determination. Keto acids were identified by paper chromatography described by Magasanik and Umbarger $^{6)}$. Amino acids were identified by paper chromatography (solvent system: 2 parts acetic acid, 1 part water and 4 parts $n$-butyl alcohol).

\section{RESULTS AND DISCUSSION}

The Determination of the Formed Higher Alcohols by Gas Chromatography.

Twenty $\mathrm{ml}$ of cell-free extract was incubat-

5) K. Yoshizawa and K. Aiba, This Journal, 26, 309 (1962).

6) B. Magasanik and H.E. Umbargcr, J. Am. Chem. Soc., 72, 2308 (1950). ed in $80 \mathrm{ml}$ of $0.04 \mathrm{M}$ phosphate buffer solution containing $320 \mathrm{mg}$ of $a$-keto- $n$-butyric acid, or an equal amount of $a$-amino- $n$-butyric acid, $100 \mathrm{mg}$ of glucose, $50 \mathrm{mg}$ of magnesium sulfate, $2.5 \mathrm{mg}$ of TPN and $5 \mathrm{mg}$ of DPN with constant shaking at $30^{\circ} \mathrm{C}$ for $\mathbf{5}$ hours. After centrifugation of the reaction mixture, $1 \mathrm{ml}$ of the supernatant fluid was used for determination and identification of keto acids and amino acids. The residual fluid was distilled to give $2 \mathrm{ml}$ of distillate after addition of $1 \mathrm{ml}$ of ethyl alcohol. After having been used for determination of the formed higher alcohols, the distillate was dehydrated with anhydrous sodium sulfate and was analyzed by gas chromatography (column used, $2.5 \mathrm{~m}$ dioctyl phthalate and $2 \mathrm{~m}$ diglycerol). The results are shown in Table II. No significant amount of higher alcohols was formed in the solution lacking either in $a$-keto- $n$-butyric acid and its amino analogue. The significant amount of higher alcohols was formed in the

TABle II. The Higher Alcohols Formed IN THE LARGE SCALE INCUBATION

$\begin{array}{llcc}\text { System used } & \begin{array}{c}\text { Active amyl } \\ \text { alcohol } \\ \text { formed } \\ \mathrm{mg} / 10 \mathrm{ml}\end{array} & \begin{array}{c}n \text {-Propyl } \\ \text { alcohol }\end{array} & \begin{array}{c}\text { Isobutyl } \\ \text { alcohol } \\ \text { formed } \\ \mathrm{mg} / 10 \mathrm{ml}\end{array} \\ \begin{array}{l}\text { Basal system* } \\ \begin{array}{l}\alpha \text {-Keto- } n \text {-butyric } \\ \text { acid added }\end{array}\end{array} & 0.04 & & 0.04 \\ \begin{array}{l}\boldsymbol{\alpha} \text {-Amino- } n \text {-butyric } \\ \text { acid added }\end{array} & 0.12 & \text { Trace } & 0.12 \\ * \quad \text { The basal system was the same as given in Table I except that } \\ \alpha \text {-keto- } n \text {-butyric acid and glucose wcre omittcd. }\end{array}$

$a$-keto-n-butyric acid solution; the results of gas chromatography showed that the higher alcohols consisted mainly of active amyl alcohol and traces of isobutyl and $n$-propyl alcohol. Under the experimental conditions used the synthesis of active amyl alcohol was thought to overcome that of $n$-propyl alcohol. The reaction mixture containing $a$-amino- $n$ butyric acid gave small amounts of higher alcohols. A trace of $a$-keto-n-butyric acid was 
detected in the reaction mixture containing $a$-amino- $n$-butyric acid. Threonine, a-amino$n$-butyric acid and isoleucine were detected in trace amounts in the reaction mixture containing $a$-keto- $n$-butyric acid.

Effect of pH on the Formation of Active Amyl Alcohol.

In the previous experiment using washed yeast cells it was found that the formation of active amyl alcohol was optimal at $\mathrm{pH} 5.2^{3)}$. As shown in Table III, the amounts of decreased $a$-keto- $n$-butyric acid and formed active amyl alcohol were largest at pH 5.2, which coincides with the optimal $\mathrm{pH}$ mentioned above.

TABLE III. EFFECT OF pH ON THE FORMATION of Active AMYL ALCOHOL

\begin{tabular}{|c|c|c|c|c|}
\hline $\begin{array}{c}\text { System } \\
\text { used }\end{array}$ & $\begin{array}{c}\alpha-\mathrm{KB}^{*} \\
\text { decreased } \\
\mathrm{mg} / 10 \mathrm{ml}\end{array}$ & $\begin{array}{c}\text { Active amyl } \\
\text { alcohol } \\
\text { formed } \\
\mathrm{mg} / 10 \mathrm{ml}\end{array}$ & $\underset{\%}{\text { Yield }}$ & $\begin{array}{c}\text { Isobutyl } \\
\text { alcohol } \\
\text { formed } \\
\mathrm{mg} / 10 \mathrm{ml}\end{array}$ \\
\hline $\mathrm{pH} 5.2$ & 2.7 & 0.80 & 36 & 0.15 \\
\hline $\mathrm{pH} 6.2$ & 2.4 & 0.25 & 13 & Trace \\
\hline $\mathrm{pH} 7.2$ & 2.2 & 0.50 & 27 & 0.10 \\
\hline
\end{tabular}

Effect of TPN, DPN, Mg and Glucose on the Formation of Active Amyl Alcohol.

Effect of TPN, DPN, Mg and glucose on the synthesis of active amyl alcohol was examined. Table IV shows the results. The reaction mixture with $a$-keto-n-butyric acid and undialyzed cell-free extract gave about twice as much active amyl alcohol as the reaction mixture with $a$-keto- $n$-butyric acid and dialyzed cell-free extract. In the same time the former gave an appreciable amount of isobutyl alcohol, a large part of which was thought to be formed from valine contained largely in undialyzed cell-free extract. When dialyzed cell-free extract was used, formation of active amyl alcohol was suppressed by addition of glucose. Omission of TPN diminished the synthesis of active amyl alcohol, and omission of DPN diminished the synthesis more largely, whereas omission of magnesium was hardly effective on the synthesis. In any case the yield of active amyl alcohol formed from decreased $a$-keto- $n$-butyric acid (11 $14 \%$ of added) was about $40 \%$ and a small amount of isobutyl alcohol was formed.

TABle IV. EFFect of TPN, DPN, MAgNesium AND GLUCOSE ON THE FORMATION OF ACTIVE AMYL ALCOHOL

$\begin{array}{lcccc}\text { System used } & \begin{array}{c}\alpha \text {-KB* } \\ \text { decreased } \\ \mathrm{mg} / 10 \mathrm{ml}\end{array} & \begin{array}{c}\text { Active amy } \\ \text { alcohol } \\ \text { formed } \\ \mathrm{mg} / 10 \mathrm{ml}\end{array} & \begin{array}{c}\text { Yield } \\ \%\end{array} & \begin{array}{c}\text { Isobutyl } \\ \text { alcohol } \\ \text { formed } \\ \mathrm{mg} / 10 \mathrm{ml}\end{array} \\ \begin{array}{l}\boldsymbol{\alpha} \text {-KB* omitted } \\ \text { Glucose added }\end{array} & 1.9 & 0.10 & & 0.05 \\ \text { Complete system } & 2.3 & 0.75 & 39 & 0.15 \\ \text { TPN omitted } & 2.0 & 0.60 & 36 & 0.10 \\ \begin{array}{l}\text { DPN omitted } \\ \text { Mg ornitted }\end{array} & 1.7 & 0.50 & 35 & 0.05 \\ \begin{array}{l}\text { Complete system } \\ \text { (undialyzed) } \\ \quad \text { * } \alpha \text {-Keto- } n \text {-butyric acid. }\end{array} & 2.0 & 0.70 & 42 & 0.20 \\ \quad \text { The complcte system was the same as given in table 1 1 except that } \\ \text { glucose was omitted. }\end{array}$

\section{SUMMARY}

1. The formation of active amyl alcohol by the use of yeast cell-free extract was examined.

2. The formation of active amyl alcohol was largest at $\mathrm{pH}$ 5.2.

3. TPN and DPN stimulated synthesis of active amyl alcohol, while magnesium was not effective on the synthesis. Addition of glucose diminished the synthesis. 